\title{
Glycosylated Haemoglobins in the Diagnosis of Diabetes Mellitus and for the Assessment of Chronic Hyperglycaemia
}

\author{
B. J. Boucher, S. G. Welch and M. S. Beer \\ Departments of Biochemistry and of Metabolism and Endocrinology, The London Hospital and The London Hospital \\ Medical College, UK
}

Summary. Evidence is presented that two levels of glycosylated haemoglobin can be defined which when exceeded indicate respectively the presence of diabetes mellitus and a significant risk for the development of microvascular complications, as judged by current glucose tolerance test criteria for such risk.

Key words: Glycosylated haemoglobin, diabetes detection, glucose tolerance tests, microvascular complications (risk of)

Glycosylated haemoglobins $\left(\mathrm{HbA}_{1}\right)$ have been shown to be raised in chronic hyperglycaemia and to correlate closely with the average degree of hyperglycaemia over several weeks before their estimation [1-3]. Since glycosylation of protein by non-enzymatic binding [4] also appears to be related to the initiation of microvascular diabetic complications [5], there is good reason to aim at reduction of such glycosylation in diabetics. Similarly, since these complications develop with hyperglycaemia, whether overt or not, there is a need for a simple method for the detection of clinically significant hyperglycaemia. $\mathrm{HbA}_{1}$ estimation appears to be such a method [6].

Evidence from long-term surveys suggests that hyperglycaemia becomes a risk factor for microvascular disease only once $2 \mathrm{~h}$ blood glucoses on oral glucose tolerance testing rise above $11.1 \mathrm{mmol} / \mathrm{l}$ $(200 \mathrm{mg} / 100 \mathrm{ml})$ [7]. The present preliminary study was made to investigate the relationship of $\mathrm{HbA}_{1}$ levels to oral glucose tolerance test (GTT) findings and to define $\mathrm{HbA}_{1}$ levels above which chronic hyperglycaemia is likely to be a risk factor using the $2 \mathrm{~h}$ glucose levels quoted above.

\section{Methods}

Glycosylated haemoglobin $\mathrm{HbA}_{1(\mathrm{a}+\mathrm{b}+\mathrm{c})}$ was measured on aliquots of fasting venous blood samples from all hospital patients referred for routine oral $50 \mathrm{~g} \mathrm{GTTs}$ over a 3 -month period, with a rapid column chromatographic method [8]. The patients were aged from 20 to the late 70 s, $65 \%$ were female, the excess being due to tests carried out during and after pregnancy. The GTTs were carried out fasting, sitting in a waiting-room, non-smoking, after 3 days adequate carbohydrate intake. The variation of the $\mathrm{HbA}_{1}$ method was $4 \%$ between and $3 \%$ within assays. A normal range was established on 206 fit young adults aged 19-21 years over 2 years. There was no significant difference between the means of values in men and women ( 65 and $35 \%$ of subjects respectively). Plasma glucose levels were measured by a standard autoanalyser glucose oxidase method [9]. Correlation coefficients and regressions were calculated by standard methods $[10,11]$.

\section{Results}

The range for $\mathrm{HbA}_{1}$ in 206 healthy young adults was 6.4 to $10.5 \%$ (mean $7.8 \% \pm 0.095 \mathrm{SE}$ ). The ranges and means for the 27 newly diagnosed diabetics and the 58 non-diabetics are also shown in Table 1 . In 27 newly diagnosed diabetics significant correlations were found between $\mathrm{HbA}_{1}$ and the fasting, $30 \mathrm{~min}$,

Table 1. Ranges and means \pm SEM for $\mathrm{HbA}_{3}$ in normal subjects, and in the subjects found to be non-diabetic or diabetic on oral glucose tolerance testing

\begin{tabular}{|c|c|c|c|c|}
\hline \multirow[t]{2}{*}{ Group } & \multirow[t]{2}{*}{ No. } & \multicolumn{3}{|l|}{$\mathrm{HbA}_{1}$} \\
\hline & & Range (\%) & Mean $(\%)$ & $\pm \mathrm{SEM}$ \\
\hline Normal subjects & 206 & $6.4-10.5$ & 7.8 & 0.095 \\
\hline Non-diabetic & & & & \\
\hline hospital patients & 58 & $6.5-10.6$ & 8.98 & 0.13 \\
\hline $\begin{array}{l}\text { Newly diagnosed } \\
\text { diabetics }\end{array}$ & 27 & $5.7-22.1$ & 15.68 & 0.53 \\
\hline
\end{tabular}


$2 \mathrm{~h}$, and summed plasma glucose levels at these times (Table 2). Four of these subjects gave $2 \mathrm{~h}$ glucose values in the border-line range but each of these gave fully diabetic levels in the other samples. Thus no border-line group was defined for study. In 58 nondiabetic GTTs there were significant positive correlations between $\mathrm{HbA}_{1}$ values and with fasting plasma glucose levels but not with the $30 \mathrm{~min}$ summed or $2 \mathrm{~h}$ levels (Table 2). Five grossly discrepant values of $\mathrm{HbA}_{1}$ and oral GTT were found to be due either to recent delivery of gestational diabetics (three patients), to acute onset insulin-requiring diabetes (one patient), and to untreated pernicious anaemia with haemolysis (one patient).

Table 2. Correlation coefficients for $\mathrm{HbA}_{1}$ levels with normal and diabetic blood glucose levels

\begin{tabular}{|c|c|c|c|c|}
\hline & \multicolumn{2}{|c|}{$\begin{array}{l}\text { Non-diabetics } \\
n=58\end{array}$} & \multicolumn{2}{|c|}{$\begin{array}{l}\text { Newly-diagnosed } \\
\text { diabetics } \\
n=27\end{array}$} \\
\hline & $r$ & $p$ & $r$ & $p$ \\
\hline \multirow{4}{*}{$\begin{array}{l}\mathrm{HbA}_{1} \text { versus fasting } \\
\text { plasma glucose } \\
\mathrm{HbA}_{1} \text { versus } 30 \mathrm{~min} \\
\text { plasma glucose } \\
\mathrm{HbA}_{1} \text { versus } 2 \mathrm{~h} \\
\text { plasma glucose } \\
\mathrm{HbA}_{1} \text { versus summed } \\
\text { plasma glucose }\end{array}$} & 0.28 & 0.02 & 0.86 & $<0.001$ \\
\hline & 0.13 & NS & 0.69 & $<0.001$ \\
\hline & 0.10 & NS & 0.68 & $<0.001$ \\
\hline & 0.24 & NS & 0.79 & $<0.001$ \\
\hline
\end{tabular}

The regression of $\mathrm{HbA}_{1}$ levels on fasting and $2 \mathrm{~h}$ plasma glucose levels were calculated (Figs. 1 and 2). The regressions indicated $\mathrm{HbA}_{1}$ levels of $10.6 \pm$ $1.5 \%$ SEM for fasting plasma glucose values of $7.0 \mathrm{mmol} / \mathrm{l}$ and levels of $12.6 \pm 1.4 \%$ SEM for $2 \mathrm{~h}$ plasma glucose values of $11.1 \mathrm{mmol} / \mathrm{l}$. Using the EASD definition of diabetes [7] and considering $\mathrm{HbA}_{1}$ levels of above our normal range of up to $10.5 \%$ to be diabetic, we would appear to be diagnosing $2 \%$ diabetic false positives on $\mathrm{Hb}_{1}$ levels without any false negative if a $2 \mathrm{~h}$ plasma glucose of $11.1 \mathrm{mmol} / \mathrm{l}$ or above were the criterion for diagnosis of diabetes. Since, however, the four subjects with lower $2 \mathrm{~h}$ glucose levels were clearly diabetic on fasting and $30 \mathrm{~min}$ samples, even with the $50 \mathrm{~g}$ load used, it apears that an $\mathrm{HbA}_{1}$ of $10.6 \%$ does satisfactorily divide our non-diabetics from those currently diagnosed as diabetic.

\section{Discussion}

Oral GTTs are made difficult to interpret by their inherent variability [12] as well as by variability in their interpretation [13]. We have used current EASD definitions in this study. If, in addition, as Jarrett and Keen [14] and Sayegh and Jarrett [15] suggest, $2 \mathrm{~h}$ blood glucose levels of $11.1 \mathrm{mmol} / \mathrm{l}$ or above after carbohydrate loads may be a threshold above which there is a risk of microvascular disease, then there should be a corresponding value of $\mathrm{HbA}_{1}$
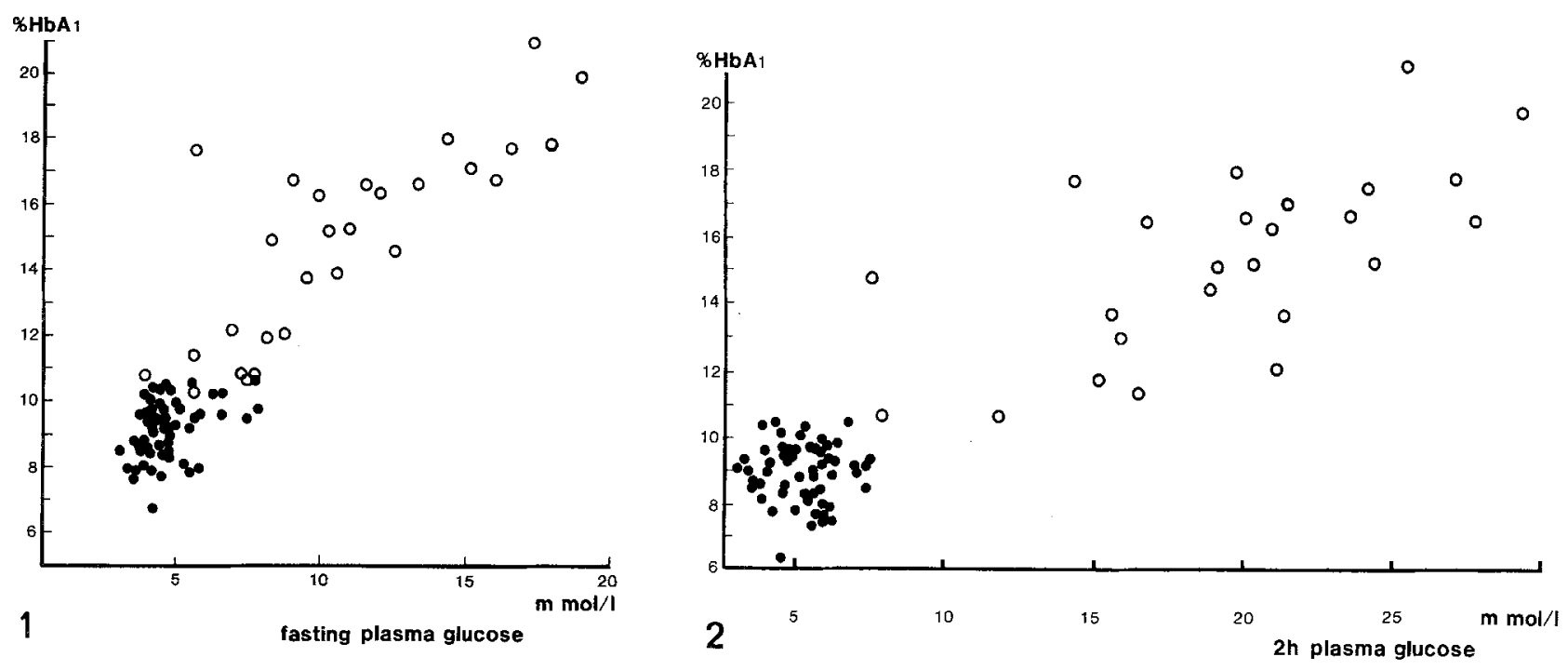

Fig. 1. Showing percentage $\mathrm{HbA}_{1}$ and fasting plasma glucose levels in the diabetics $(O)$ and nondiabetics $(\bullet)$ found on oral GTTs. (Diabetics $r=0.86, p \leqslant 0.001$; non-diabetics $r=0.28, p \leqslant 0.02$ )

Fig. 2. Showing percentage $\mathrm{HbA}_{1}$ and $2 \mathrm{~h}$ plasma glucose levels for diabetics (O) and non-diabetics ( $)$ identified on oral GTTs. (Diabetics $r=0.68, p \leqslant 0.001$; non-diabetics $r=0.1 \mathrm{NS}$ ) 
reflecting protein glycosylation above which this risk is present. Long-term studies will be needed to establish properly such thresholds for $\mathrm{HbA}_{1}$ levels, measured by standardized methods, as a risk factor, but in the interim, values defined in the way that has been done in this study may be useful both in diagnosis and in the management of diabetes. Thus using the present method of $\mathrm{HbA}_{1}$ estimation, levels of $10.6 \%$ and above indicate that diabetes mellitus is present. $\mathrm{HbA}_{1}$ levels may make useful 'spot tests' for the detection of diabetes except in the presence of haemolysis, in diabetes of very recent onset, or where early diagnosis is vital as in pregnancy. The advantages of $\mathrm{HbA}_{1}$ estimation are those of a simple procedure, lack of any need for dietary preparation or for fasting, elimination of the variability usually found on oral glucose tolerance tests as well as accurate reflections of overall chronic hyperglycaemia [3].

In attempts to assess glycaemia as a risk factor in diabetics it is necessary to avoid interference from short-term increased glycosylation. Storage of blood in sequestrene for $24 \mathrm{~h}$ pre-assay should allow removal of such short-term adducts [16]. Samples for long-term assessment should be taken when patients have apparently been fit and well, since values will be raised following acute failures of control (e.g. hyperglycaemic ketoacidosis or hyperosmolar coma). Within these constraints, levels of $12.6 \%$ and above in our laboratory are indications that hyperglycaemia is likely to be a significant risk for the development of microvascular complications. At present 60 and $40 \%$ of our current patients on treatment with or without insulin respectively fall into this category (unpublished data). Patients whose $\mathrm{HbA}_{1}$ levels we find to lie between 10.5 and $12.6 \%$ can be considered to be borderline as regards the presence of hyperglycaemia as a significant risk factor. Standardization of methods, the establishment of normal ranges and studies versus oral GTT findings should add considerably to the usefulness of individual laboratories' $\mathrm{HbA}_{1}$ levels for the diagnosis and long-term followup of diabetics.

Acknowledgements. The authors are grateful to Dr. Houghton and the staff in The Clinical Chemistry Department at The London Hospital for the preservation of basal blood samples from oral GTT and to Mr. Stephen Evans for guidance and practical help with the statistical analyses.

\section{References}

1. Gonen B, Rubenstein AH, Rochman $\mathrm{H}$, Tanega SP, Horwitz DL (1977) Haemoglobin $A_{1}$; an indicator of the metabolic control of diabetic patients. Lancet 2: 734-736

2. Leslie RDG, Pyke DA, John PN, White JM (1978) Haemoglobin $A_{1}$ in diabetic pregnancy. Lancet 2: 958-959

3. Paisey RB, Macfarlane DG, Sherriff RJ, Hartog M, Slade RR, White DAJ (1980) The relationship between glycosylated haemoglobins and home capillary blood glucose levels in diabetics. Diabetologia 19: 31-34

4. Spicer KM, Allen RC, Hallet D, Buse MG (1979) Synthesis of haemoglobin $A_{1 c}$ and related minor haemoglobin by erythrocytes. J Clin Invest 64: 40-48

5. Chang AY, Noble RE (1979) Estimations of $\mathrm{HbA}_{\mathrm{Ic}}$-like glycosylated protein in the kidneys of streptozotocin-diabetic and control rats. Programme: ADA 39th Ann Meeting. Diabetes 28: 408

6. Lev-Ran A, Vanderlaan WP (1979) Glycohaemoglobins and glucose tolerance. J Am Med Assoc 241: 912-914

7. Keen H, Jarrett RJ, Alberti KG (1979) Diabetes mellitus; a new look at diagnostic criteria (Editorial). Diabetologia 16: 283-285

8. Welch SG, Boucher BJ (1978) A rapid microscale method for

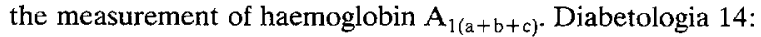
209-211

9. Trinder P (1969) Determination of glucose in blood using glucose oxidase with an alternative oxygen acceptor. Ann Clin Biochem 6: 24-27

10. Snedecor GW, Cochran WG (1967) Statistical methods, 6th edn. Iowa State University Press, Iowa

11. Siegel S (1956) Non-parametric statistics for the behavioural sciences. McGraw-Hill, New York

12. Jarrett RJ (1973) Problems of the glucose tolerance test. Br J Hosp Med 10: 578-580

13. West KM (1975) Substantial differences in the diagnostic criteria used by diabetes experts. Diabetes 24: 641-644

14. Jarrett RJ, Keen H (1976) Hyperglycaemia and diabetes mellitus. Lancet 2: 1009-1012

15. Sayegh HA1, Jarret RJ (1979) Oral glucose-tolerance tests and the diagnosis of diabetes: results of a prospective study based on the Whitehall survey. Lancet 2: 431-435

16. Welch SG (1979) Fast glycosylation of haemoglobin. Lancet 1: 728

Received: 11 November 1980

and in revised form: 30 December 1980

Dr. B. J. Boucher,

The Metabolic and Endocrine Unit,

The London Hospital

London E1

U.K. 